\title{
Effect of replacement of milk by block freeze concentrated whey in physicochemical and rheological properties of ice cream
}

\author{
Eulália Lopes da Silva BARROS ${ }^{1}$ (D), Callebe Camelo SILVA ${ }^{1}$, Maria Helena Machado CANELLA², \\ Silvani VERRUCK ${ }^{2}$, Amanda Alves PRESTES ${ }^{1}$, Maryella Osório VARGAS ${ }^{2}$, Bruna Marchesan MARAN ${ }^{1}$, \\ Erick Almeida ESMERINO ${ }^{3}$, Ramon SILVA ${ }^{3}$, Celso Fasura BALTHAZAR ${ }^{4}$, Veronica Maria de Araujo CALADO ${ }^{5}$, \\ Elane Schwinden PRUDENCIO ${ }^{1,2 *}$
}

\begin{abstract}
This study's main highlight to the effect of replacement of milk by different proportions of concentrated whey in the elaboration of ice creams and the characterization of their physicochemical and microstructural properties. Ice creams have high levels of total solids, acidity, and low pH values. All ice creams exhibited Newtonian fluid behaviors while the Power and Casson Law model adequately explained the flow properties. Viscosity and hysteresis area increased as a higher ratio of concentrated whey was added. Ice cream formulations containing a higher proportion of milk showed greater brightness, the ice creams showed a greenish-yellow coloring tendency. The overrun values ranged from 27 to $44 \%$, and ice cream with partial replacement of milk by concentrated whey showed greater resistance to melting. The addition of concentrated whey did not influence the size of the ice crystals, fat globules, and air bubble diameters. However, the higher total solids content influenced the texture of the ice creams, promoting smoother and creamy ice creams. These results highlight the application of concentrated whey on the 50\% substitution level, thus being an attractive alternative for the food industry, mainly about the cost-benefit and added value to the product, by enhancing the color, flavor, and texture.
\end{abstract}

Keywords: ice cream; whey; overrun; physical properties; freeze concentration process.

Practical Application: Use of by-products from the dairy industry for the production of ice cream.

\section{Introduction}

The use of secondary products such as whey has been increasingly studied because is a cheap and easily available product. The proteins from whey confer improvement in some properties, such as helping in the emulsification, foaming, and stability of food (Silva \& Bolini, 2006). The high content of organic matter present in whey is responsible for causing serious pollution problems, especially when improperly discarded. By studying the technological whey properties, new ways of using this product can be developed (Masotti et al., 2017). The use of technologies such as block freeze concentration can be the solution to the problem of whey management, aiming to add value and reduce the volume and disposal costs. According to Sánchez et al. (2011a), this technology is capable of concentrating liquids by freezing and removing part of the water without causing damage to thermally sensitive compounds. The process is based on the recovery of a food solute by the separation of pure ice crystals freezing concentrated aqueous phase. Also, Sánchez et al. (2011a) highlights that the operating cost of the block freeze concentration process is three times cheaper compared to other processes such as evaporation or reverse osmosis, considering costs, cleaning, and energy. The freeze concentrated has before now been applied to whey (Sánchez et al., 2011a; Canella et al., 2018), however, no replacement of milk by concentrated whey was reported in ice cream until now.

Hasan et al. (2020) stated that the ice cream is a popular frozen dairy product over the world, and there are many types of ice cream that differ according to additives and manufactured way. Over the past 20 years, ice cream technology has improved significantly ( $\mathrm{Al}$ et al., 2020). The ice cream consists of a food complex system, consisting of a frozen matrix containing air bubbles, fat globules, ice crystals, and an unfrozen whey phase. It can be considered a nutritious food due to the presence of protein, vitamins, and minerals (Bahram-Parvar et al., 2015). In addition, ice cream has a significant market because pleases many consumers, but acceptance depends greatly on its quality, flavor, and texture. Chemical and physical properties are essential to the structure of ice cream and differ depending on formulation and processing conditions (Balthazar et al., 2017a; Acu et al., 2020). These structural attributes and the composition are essential for the behavior of the ice cream. Preparation of ice cream with added whey can be performed aiming an improvement in structural

${ }^{1}$ Centro Tecnológico, Programa de Pós-Graduação em Engenharia de Alimentos, Universidade Federal de Santa Catarina (UFSC), Florianópolis, SC, Brasil.

${ }^{2}$ Centro de Ciências Agrárias, Programa de Pós-Graduação em Ciência dos alimentos, Universidade Federal de Santa Catarina (UFSC), Florianópolis, SC, Brasil.

${ }^{3}$ Universidade Federal Rural de Rio do Janeiro (UFRRJ), Rio de Janeiro, RJ, Brasil

${ }^{4}$ Faculdade de Veterinária, Universidade Federal de Fluminense (UFF), Niterói, RJ, Brasil.

${ }^{5}$ Escola de Química (EQ), Universidade Federal de Rio do Janeiro (UFRJ), Rio de Janeiro, RJ, Brasil.

*Corresponding author: elane.prudencio@ufsc.br 
properties, such as viscosity, emulsification, and stability as well as reducing production costs by replacing milk with whey.

This study aimed to investigate the potential use of concentrated whey as a milk substitute in the preparation of ice creams, as well as to evaluate its influence on the physicochemical, color, rheological and microstructural properties.

\section{Material and methods}

\subsection{Material}

Pasteurized whole milk (Holandês ${ }^{\circledR}$, Papenborg Laticínios, Biguaçu-SC, Brazil) with $12.03 \mathrm{~g} / 100 \mathrm{~g}$ of total solids, $3.35 \mathrm{~g} / 100 \mathrm{~g}$ of lipids, $3.15 \mathrm{~g} / 100 \mathrm{~g}$ of protein, $0.78 \mathrm{~g} / 100 \mathrm{~g}$ of ash, and $4.75 \mathrm{~g} / 100 \mathrm{~g}$ of carbohydrate and commercial rennet, a chymosin produced by Aspergillus niger var. awamorii (with a force of $1: 3000$, Ha $\mathrm{La}^{\oplus}$, CHR HANSEN, Valinhos, Brazil) were used for obtaining the cheese whey. The ice creams were elaborated using as ingredients: pasteurized whole milk (Holandês ${ }^{\oplus}$, Papenborg Laticínios, Biguaçu-SC, Brazil), fresh milk cream (45 g/100 g of fat, Tirol, Treze Tílias, Brazil), sodium chloride (Cristalino ${ }^{\circ}$, Ciasal Indústria Salineira, Areia Branca, Brazil), and sucrose (Camil Alimentos, São Paulo, Brazil). All reagents used were of analytical grade.

\subsection{Manufacture of cheese whey}

The whey was obtained by the manufacture of Minas Frescal cheese. The cheese was prepared using a $30 \mathrm{~L}$ container of pasteurized whole milk heated to $37 \pm 1{ }^{\circ} \mathrm{C}$, sequentially was added a commercial rennet in a concentration of $0,9 \mathrm{~mL} / \mathrm{L}$ and incubated at $37 \pm 1{ }^{\circ} \mathrm{C}$ for 40 minutes. The resulting gel was cut, drained, and placed in perforated cylindrical packages with a capacity of $500 \mathrm{~g}$ each, given maximum whey release. The cheese whey obtained was filtered and frozen at $-20 \pm 1{ }^{\circ} \mathrm{C}$ until the freeze concentration process.

\subsection{Protocol of cheese whey freeze concentration process}

The block freeze concentration method was used for the whey concentration, according to the methodology described by Canella et al. (2018). At each stage of the block freeze concentration process, two fractions named freeze concentrated whey $(\mathrm{CW})$ and ice (I) were obtained (Figure 1).

\subsection{Total solids content}

For calculations of concentration factor and process efficiency, the whey concentrates (CW1, CW2, and CW3), and ices (I1, I2, and I3) were evaluated to the total solids content $(\mathrm{g} / 100 \mathrm{~g})$. The analysis was performed by drying the samples at $105 \pm 1{ }^{\circ} \mathrm{C}$ until constant weight, as described in IDF (International Dairy Federation, 2013).

\subsection{Concentration factor}

The concentration factor (CF) was calculated for each stage of freeze concentration, according to the methodology presented by Canella et al. (2018), using Equation 1:

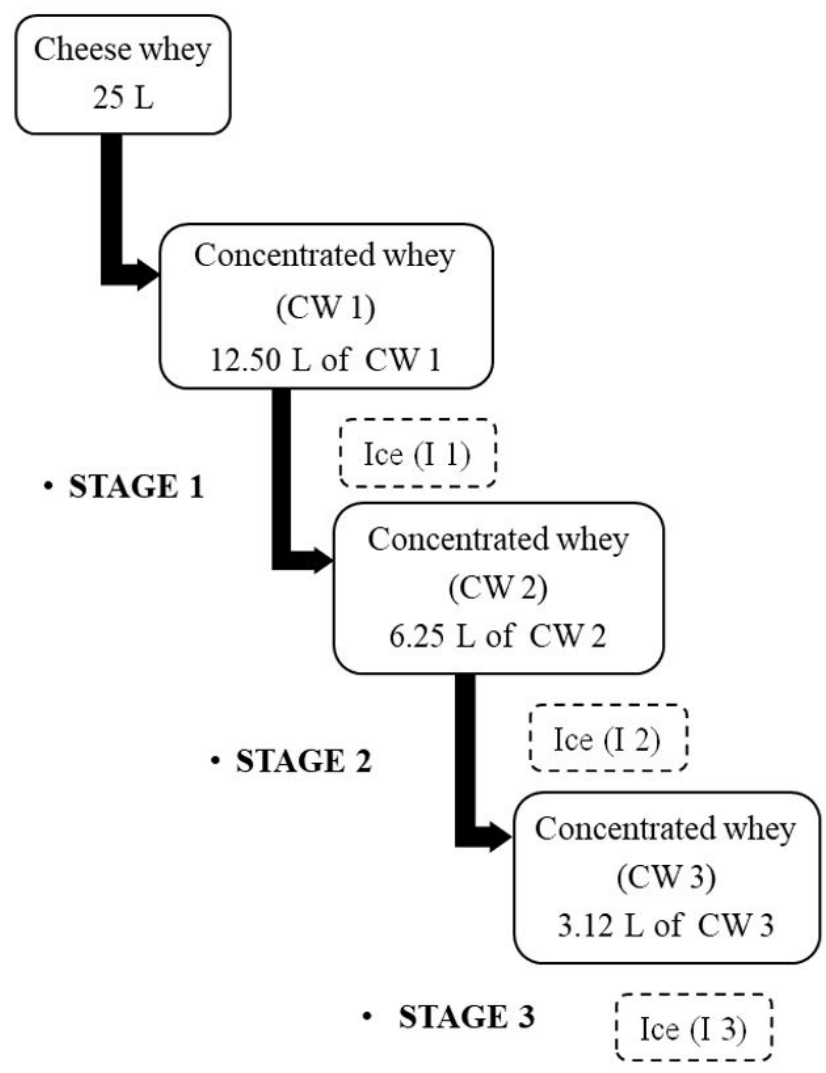

Figure 1. Block freeze concentration process of cheese whey.

$$
\mathrm{CF}(\%)=\frac{\mathrm{TS}_{\mathrm{wc}}}{\mathrm{TS}_{0}} \times 100
$$

where, $\mathrm{TS}_{\mathrm{wc}}$ is the total solids content $(\mathrm{g} / 100 \mathrm{~g})$ of the concentrated whey at each stage of freeze concentration and $\mathrm{TS}_{0}$ is the total solids content $(\mathrm{g} / 100 \mathrm{~g})$ of the initial cheese whey.

\subsection{Process efficiency}

The process efficiency (PE) of freeze concentration was calculated by the following equation (Equation. 2):

$\operatorname{PE}(\%)=\frac{\mathrm{TS}_{\mathrm{C}}-\mathrm{TS}_{\mathrm{G}}}{\mathrm{TS}_{\mathrm{C}}} \times 100$

where it was determined by the increase in total solids content (TS) in the concentrated $\left(\mathrm{TS}_{\mathrm{C}}\right)(\mathrm{g} / 100 \mathrm{~g})$ to the total solids content (TS) remaining in the ice $\left(\mathrm{TS}_{\mathrm{G}}\right)(\mathrm{g} / 100 \mathrm{~g})$ of each stage of the freeze concentration process.

The concentrated whey used in the preparation of the ice creams was chosen from the evaluated results of the process efficiency (PE) and the concentration factor (CF).

\subsection{Validation of experimental results}

To validate the experimental results the mass balance was calculated, following the methodology by Sánchez et al. (2011b). It was made a comparison between the mass balance and the theoretical data by calculation of the predicted ice mass ratio (Wpred) (kg of ice per $\mathrm{kg}$ of cheese whey), according to Equation 3. 
$\mathrm{W}($ pred $)=\frac{\mathrm{TS}_{\mathrm{Si}}-\mathrm{TS}_{\mathrm{CW}}}{\mathrm{TS}_{\mathrm{I}}-\mathrm{TS}_{\mathrm{cw}}}$

where, $\mathrm{TS}_{\mathrm{Si}}$ is the initial content of total solids ( $\mathrm{g} / 100 \mathrm{~g}$ ) of whey, $\mathrm{TS}_{\mathrm{Cw}}$ the content total solids $(\mathrm{g} / 100 \mathrm{~g})$ of concentrated whey (CW) and $\mathrm{TS}_{\mathrm{I}}$ is the total solids content of the ice fraction (I).

The deviation between experimental and theoretical data was expressed as the root mean square (RMS) deviation, using Equation 4.

$$
\operatorname{RMS}(\%)=\sqrt{\frac{\left(\mathrm{W}_{\mathrm{EXP}}-\mathrm{W}_{\text {pred }} / \mathrm{W}_{\mathrm{EXP}}\right)^{2}}{\mathrm{~N}}} \times 100
$$

where Wexp and Wpred represent the experimental and predicted proportions from the mass of ice, respectively, while $\mathrm{N}$ is the number of repetitions performed.

\subsection{Elaboration of ice creams}

Five formulations of ice creams were elaborated according to the methodology by Silva et al. (2015), with modifications. The ice cream denominated ice cream 1 is the control sample, prepared with pasteurized milk, the ice cream denominated ice cream (2, 3,4 , and ice cream 5) were prepared with different proportions of concentrate whey, as described in Table 1. The ingredients of each ice creams were mixed and subjected to heat treatment for 30 minutes at $70 \pm 1{ }^{\circ} \mathrm{C}$, posteriorly were cooled and taken to the ice cream maker (Cuisinart ICE 21, New Jersey, USA), where they went through the process of beating and freezing. Finally, the ice creams were stored at $-20 \pm 2{ }^{\circ} \mathrm{C}$ until analysis. All formulations of ice creams were produced in triplicate.

\subsection{Ice cream analysis}

\section{Physicochemical analysis}

The ice creams samples (1, 2, 3, 4, and 5) were analyzed for their physicochemical characteristics. The acidity was determined according to AOAC (Association of Official Analytical Chemists, 2019), total solids as described in IDF (International Dairy Federation, 2013), and the $\mathrm{pH}$ was determined using $\mathrm{pHmeter}$ (PHS-3 BW, BEL, Piracicaba, São Paulo, Brazil).

\section{Overrun}

The overrun of the ice cream samples was determined according to Silva et al. (2015). A certain amount of ice cream syrup mass $\left(\mathrm{S}_{\mathrm{ic}}\right)$ and other amounts of a mass of ice cream $\left(\mathrm{F}_{\mathrm{ic}}\right)$ were weighed and the excess was calculated using Equation 5. The analysis was performed in duplicate.
$\operatorname{Overrum}(\%)=\frac{\left(\mathrm{S}_{\mathrm{ic}}-\mathrm{F}_{\mathrm{ic}}\right)}{\mathrm{F}_{\mathrm{ic}}} \times 100$

\section{Melting behavior}

The melting behavior was measured as proposed by Silva et al. (2015), with some modifications. In one week of frozen storage, $70 \mathrm{~g}$ of the ice cream samples were left to melt at $25 \pm 1{ }^{\circ} \mathrm{C}$ on a $2.0 \mathrm{~mm}$ wire mesh screen over a graduated cylinder. The dripped volume was recorded every $5 \mathrm{~min}$. The time ( $\mathrm{min}$ ) was plotted against the melted mass (g), aiming at obtaining a sigmoidal curve representing the kinetics of the melting process. The slope of the curve was taken as the melting rate $(\mathrm{g} / \mathrm{min})$. The analysis was performed in triplicate.

\section{Color analysis}

The color analysis of ice cream samples was determined using a colorimeter (Minolta Chroma Meter CR-400, Osaka, Japan), adjusted to operate with illuminant D65 and angle of observation of $10^{\circ}$, previously calibrated. The total color difference $\left(\Delta \mathrm{E}^{\star}\right)$ between the measured values in the control ice cream (ice cream 1$)$ to ice creams $(2,3,4$, and 5) was calculated as described by (Okpala et al., 2010). The CIELab color scale was used to calculate the parameters $\mathrm{L}^{*}, \mathrm{~b}^{*}$, and $\mathrm{a}^{*}$, which $L^{*}$ is the brightness of the ice cream (scale $1-100), a^{*}$ is the red and green balance, $b^{*}$ is the yellow and blue balance. The analysis was performed in triplicate.

\section{Distribution of ice crystals, air bubbles size, and fat particle}

The distribution of ice crystals, air bubbles size, and fat particles were assessed at $-4{ }^{\circ} \mathrm{C}$ by optical light microscopy (AXIO Image. A2m, Carl Zeiss, Germany) using 50× magnification, according to Balthazar et al. (2017b). The samples were moved directly from the freezer to the glove box $\left(-4^{\circ} \mathrm{C}\right)$ for preparation. A drop of chilled kerosene was added to aid in dispersing the ice crystals and to increase the resolution of the generated image. Ice crystals, fat particles, and air bubbles images were captured by a digital camera (AxioCamMRc 5, Zeiss, Germany) and edited using the AXIO Vision Rel. 4.8 software (Microscope Software AxioVision LE, Zeiss, Germany). For each sample, 20 structures were measured $(\mu \mathrm{m})$ in 10 microscope spots.

\section{Texture parameters}

The texture of the ice cream samples was evaluated using a texturometer TA.HD.plusTexture Analyser (Stable Micro Systems, Godalming, Inited Kingdom) accompanied by the Exponent program version 6.1.1.0 (Stable Micro Systems,

Table 1. Ice cream composition.

\begin{tabular}{|c|c|c|c|c|c|}
\hline Sample & $\begin{array}{l}\text { Concentrated milk } \\
\text { whey g/100 g }\end{array}$ & $\begin{array}{l}\text { Pasteurized milk } \\
\mathrm{g} / 100 \mathrm{~g}\end{array}$ & $\begin{array}{c}\text { Fresh milk cream } \\
\mathrm{g} / 100 \mathrm{~g}\end{array}$ & $\begin{array}{c}\text { Sodium Chloride } \\
\mathrm{g} / 100 \mathrm{~g}\end{array}$ & Sucrose g/100 g \\
\hline Ice cream 1 & - & 280 & 72.8 & 0.28 & 100.8 \\
\hline Ice cream 2 & 280 & - & 72.8 & 0.28 & 100.8 \\
\hline Ice cream 3 & 70 & 210 & 72.8 & 0.28 & 100.8 \\
\hline Ice cream 4 & 140 & 140 & 72.8 & 0.28 & 100.8 \\
\hline Ice cream 5 & 210 & 70 & 72.8 & 0.28 & 100.8 \\
\hline
\end{tabular}


Godalming, Inited Kingdom). The samples were maintained at a temperature of $-20 \pm 2{ }^{\circ} \mathrm{C}$ during the time of analysis. For each sample, five measures were realized and the following parameters were employed: test speed of $2.0 \mathrm{~mm} / \mathrm{s}$; a distance of $10.0 \mathrm{~mm}$; the height of $20 \mathrm{~mm}$, and a proof body (probe) of aluminum of $490 \mathrm{~mm}$. From the TPA curve, they have obtained the parameters: firmness $(\mathrm{N})$ and adhesiveness (N.s).

\section{Rheological measures}

The ice creams samples were submitted to the rheological measures using a concentric cylinder rotational rheometer (Brookfield Engineering Laboratories model DV-III Ultra, Stoughton, MA, USA) with spindle ULA, and were collected through the Rheocalc 32 software version 3.2 (Brookfield Engineering Laboratories, Inc., Middleboro, MA, USA). The rheometer was thermostatically controlled by a circulating water bath (TECHNAL model TE-184, São Paulo, Brazil) at $4.0 \pm 0.1^{\circ} \mathrm{C}$, to ensure temperature stability the samples were allowed to stand for $10 \mathrm{~min}$. The flow and viscosity curves were generated by the linear increase of the strain rate from $125 \mathrm{~s}^{-1}$ the $269 \mathrm{~s}^{-1}$ in the first 4 minutes (upward curve) and returned to $125 \mathrm{~s}^{-1}$ in the following 4 minutes (downward curve). The speed of rotation was increased from $1 \mathrm{rpm}$ to $130 \mathrm{rpm}$, increasing $1 \mathrm{rpm}$ each $2 \mathrm{~s}$. The flow behavior was explained through the Power Law and the Casson model, according to Equations 6 and 7 respectively:

$\sigma=\mathrm{K}(\dot{\gamma})^{\mathrm{n}}$

$\sigma^{0.5}=\sigma_{0}^{0.5}+\left(\eta_{\mathrm{c}} \dot{\gamma}\right)^{0.5}$

where $\sigma$ is the shear stress $(\mathrm{Pa}), \dot{\gamma}$ is the strain rate $\left(\mathrm{s}^{-1}\right), \mathrm{K}$ is the Consistency index $\left(\mathrm{Pa} \mathrm{s}^{-1}\right), \mathrm{n}$ is the flow behavior index, $\sigma_{0}$ is yield limit $(\mathrm{Pa})$ and $\eta_{\mathrm{c}}$ is the Casson viscosity ( $\mathrm{Pa} \mathrm{s}$ ). The behavior of the samples was evaluated by the hysteresis area calculation between the upward and downward flow curves.

\subsection{Statistical analysis}

The results were expressed as mean and standard deviation. The one-way analysis of variance (ANOVA) and Tukey test $(P<0.05)$ were used to determine the significant differences between the samples. The validity of the Power Law and Casson models was evaluated based on the coefficient of determination $\left(\mathrm{R}^{2}\right)$. The data were obtained using STATISTICA 13.3 (TIBCO Software Inc., Palo Alto, CA).

\section{Results and discussion}

\subsection{Block freeze concentration process}

Table 2 shows the performance of the block freeze concentration process obtained from the total solids content of the concentrates and ice fractions. An increase $(P<0.05)$ of the concentration factor (CF) was observed according to the evolution of the freeze concentration stages. This result is expected because the CF is directly related to the total solids content, increasing the value as the total solids increase. Regarding the process efficiency (PE), there was a decrease $(P<0.05)$ in the value with the evolution of the freeze concentration stages, noting that the PE depends directly on the total solids content in the ice fraction. As the total solids content retained in the ice fraction increases the process efficiency decreases.

For the validation of the results of the freeze concentration process, the comparison of the mass balance data, theoretical and experimental data showed a good agreement (Figure 2). The root means square deviation defined the deviation between theoretical and experimental assumptions. A good process adjustment was observed, where the RSME (\%) values ranged from $2.97 \%$ to $19.04 \%$. All values were below $25 \%$, showing an acceptable fit, as described by Canella et al. (2019).

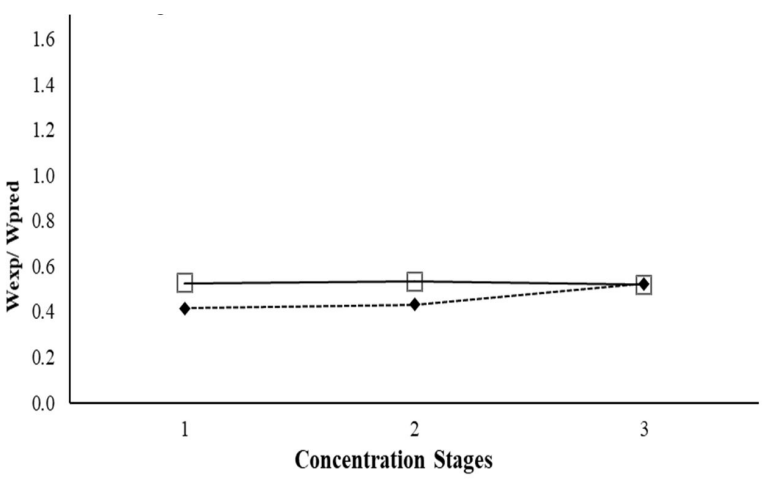

Figure 2. Experimental ( $\square$ ) and theoretical (- $\downarrow$-) results of ice mass as a function of freeze concentration stages.

Table 2. Total whey solids, concentrated whey (CW), and ice fractions (I) of each freeze concentrated stage and the concentration factor (CF) and process efficiency $(\mathrm{PE})$ to the total solids content.

\begin{tabular}{ccccc}
\hline & & Total solids $(\mathrm{g} / 100 \mathrm{~g})$ & CF $(\%)$ & PE $(\%)$ \\
\hline Whey & & $6.55 \pm 0.06^{\mathrm{dB}}$ & - & - \\
Stage 1 & CW1 & $11.29 \pm 0.09^{\mathrm{c}}$ & $172.28 \pm 3.09^{*}$ & $-93.35 \pm 0.26^{\star}$ \\
& I1 & $0.75 \pm 0.02^{\mathrm{D}}$ & - & - \\
Stage 2 & CW2 & $18.61 \pm 1.26^{\mathrm{b}}$ & $284.04 \pm 21.91^{\star}$ & $-92.65 \pm 0.90^{\star}$ \\
& I2 & $1.37 \pm 0.04^{\mathrm{C}}$ & - & - \\
Stage 3 & CW3 & $29.02 \pm 1.06^{\mathrm{a}}$ & $442.77 \pm 19.90^{+}$ & $68.53 \pm 2.72^{*}$ \\
& I3 & $9.12 \pm 0.56^{\mathrm{A}}$ & - & - \\
\hline
\end{tabular}

Results expressed as mean \pm standard deviation, among three batches performed in triplicate for each freeze concentrated stage, with three replications for total solids, $\mathrm{CF}$, and $\mathrm{PE}$; ${ }^{\mathrm{a}, \mathrm{b}, \mathrm{c}, \mathrm{d}}$ For the same column, means \pm standard deviations with different superscript lowercase letters indicate significant differences $(P<0.05)$ between whey and CW at each freeze concentrated stage; ${ }^{A, B, C, D}$ For the same column, means \pm standard deviations with different superscript capital letters indicate significant differences $(P<0.05)$ between whey and the I of each freeze concentrated stage; ${ }^{* \bullet}$ In the same column, means \pm standard deviations with different symbols indicate significant differences $(P<0.05)$ in $C F$ and $P E$ of each freeze concentrated stage. 
Based on these results, the freeze concentrate whey of the second stage (CW 2) was used in ice creams preparation.

\subsection{Ice cream analysis}

The results of the physicochemical parameters of the ice creams are presented in Table 3. It was observed that the total solids content of ice creams increased $(P<0.05)$ with the increase of concentrate whey in the ice cream formulations. The ice creams showed a decrease in $\mathrm{pH}$ and an increase in titratable acidity with the addition of concentrate whey, is that ice cream 2 presented higher acidity and lower $\mathrm{pH}$ value. As noted by Canella et al. (2019) in the freeze concentration process, the high concentration of total solids improved the high inclusion of proteins. According to Rodrigues et al. (2011), high amounts of protein can increase buffering in dairy products and cause variations in acidity and $\mathrm{pH}$.

According to Karaca et al. (2009), air incorporation may vary according to different elaboration procedures and ingredients of ice cream. The overrun results obtained in this study are presented in (Table 3). The ice creams $(3,4$, and 5) presented the highest values of overrun. Besides, there was no significant difference in overrun values between ice cream 1 and ice cream 2. In general, low levels of air incorporation are observed in the samples of this study and this could be attributed to the poor foaming ability of whey. Levin et al. (2016) reported that the formation of foam directly influences ice creams aeration. Bahram-Parvar et al. (2015) suggested the reduction in air incorporation is also correlated with increases in formulation viscosities of the ice cream. The high viscosity does not favor the foaming formation. Relkin \& Sourdet (2005) reported that the whey proteins present, in their denatured state, interact with themselves and casein micelles, increasing the viscosity of the ice cream formulations. The overrun values found in this study are by the acceptable range for traditional ice cream.

Figure 3 shows the evolution of the melted ice cream mass over time, in the form of sigmoidal curves. Ice cream 1 lost its shape faster than the ice creams $(2,3,4$, and 5), which retained its original shape longer. As reported by Kirtil \& Oztop (2016) this effect was probably a result of the total solids content of milk whey and consequently of the protein content present, because proteins delay the melting of ice cream due to its emulsifying property. It was observed that ice cream 2 showed similar behavior to control (ice cream 1), which is explained by their amount of air incorporated. According to Balthazar et al. (2018) overrun is important in determining the melting rate. The ice creams that exhibit low overrun also have a slower melting rate.

The values for the color parameters are presented in Table 3. Ice cream 2 presented the lower $(P<0.05)$ whiteness between the samples, once the presence of milk contributes to an increase in the whiteness of the ice creams. As reported by Scarso et al. (2017) the presence of tiny fat globules together with colloidal casein particles and calcium phosphate are responsible for the white color of milk. Negative values of $\mathrm{a}^{*}$ and positives values of $\mathrm{b}^{*}$ indicate that the ice creams tend to green and yellow color, respectively. The highest intensity of green and yellow color was observed in the ice creams with concentrated whey addition. According to the values of the total color difference $\left(\Delta \mathrm{E}^{\star}\right)$, the ice creams with the higher addition of concentrated whey were more affected. The replacement of milk by whey in 50, 75, and $100 \%$ were visible to the human eye. According to MartínezCervera et al. (2011), the total color difference $\left(\Delta \mathrm{E}^{\star}\right)$ values can be visually perceived by the human eye when the values were greater than 3 .

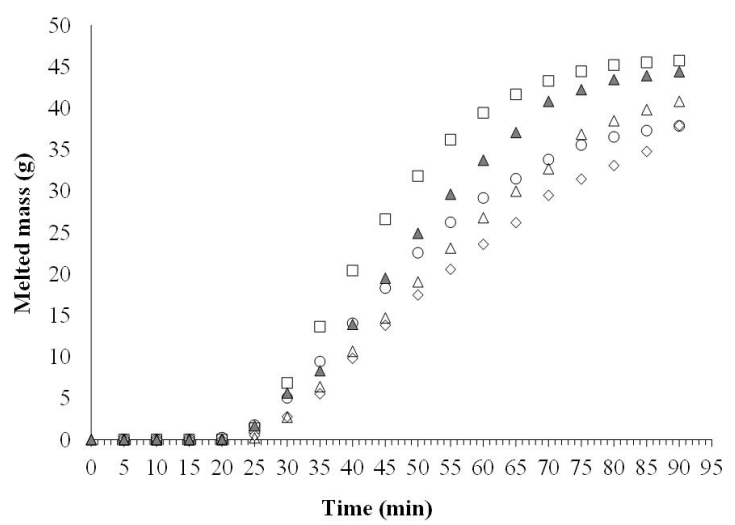

Figure 3. Melting behavior of ice cream produced with pasteurized whole milk (Ice cream 1) $(\Delta)$; freeze concentrated whey - Ice cream 2 (०); $25 \%$ of freeze concentrated whey and $75 \%$ of pasteurized whole milk - Ice cream $3(\boldsymbol{\Delta})$; $50 \%$ of freeze concentrated whey and $50 \%$ of pasteurized whole milk - Ice cream $4(\diamond)$ and $75 \%$ of freeze concentrated whey and $25 \%$ of pasteurized whole milk - Ice cream 5 ( $\square$ ).

Table 3. Physical and chemical parameters of the ice creams.

\begin{tabular}{|c|c|c|c|c|c|}
\hline & Ice cream 1 & Ice cream 2 & Ice cream 3 & Ice cream 4 & Ice cream 5 \\
\hline Total solids (g/ $100 \mathrm{~g})$ & $34.75 \pm 0.37^{c}$ & $40.82 \pm 0.36^{\mathrm{a}}$ & $34.59 \pm 1.10^{c}$ & $36.98 \pm 0.00^{b}$ & $40.38 \pm 1.52^{\mathrm{a}}$ \\
\hline Titratable acidity (g / 100 g) & $0.17 \pm 0.01^{\mathrm{d}}$ & $0.39 \pm 0.01^{\mathrm{a}}$ & $0.19 \pm 0.01^{\mathrm{d}}$ & $0.27 \pm 0.03^{c}$ & $0.33 \pm 0.01^{\mathrm{b}}$ \\
\hline $\mathrm{pH}$ & $6.73 \pm 0.02^{\mathrm{a}}$ & $0.49 \pm 0.01^{\mathrm{e}}$ & $6.65 \pm 0.01^{\mathrm{b}}$ & $6.59 \pm 0.01^{\mathrm{c}}$ & $6.53 \pm 0.01^{\mathrm{d}}$ \\
\hline Overrun & $27.49 \pm 1.60^{\mathrm{b}}$ & $27.28 \pm 2.18^{b}$ & $42.30 \pm 0.65^{\mathrm{a}}$ & $43.85 \pm 2.51^{\mathrm{a}}$ & $33.51 \pm 6.85^{\mathrm{ab}}$ \\
\hline $\mathrm{L}^{*}$ & $86.38 \pm 1.37^{\mathrm{a}}$ & $82.45 \pm 0.52^{b}$ & $86.14 \pm 0.04^{\mathrm{a}}$ & $86.85 \pm 0.90^{\mathrm{a}}$ & $87.65 \pm 0.94^{\mathrm{a}}$ \\
\hline$b^{*}$ & $14.49 \pm 0.26^{c}$ & $17.65 \pm 0.31^{\mathrm{a}}$ & $16.27 \pm 0.63^{b}$ & $17.78 \pm 0.42^{\mathrm{a}}$ & $18.02 \pm 0.44^{\mathrm{a}}$ \\
\hline$a^{*}$ & $-3.34 \pm 0.11^{\mathrm{a}}$ & $-4.32 \pm 0.15^{\mathrm{d}}$ & $-3.67 \pm 0.14^{b}$ & $-3.98 \pm 0.17^{c}$ & $-4.05 \pm 0.10^{c}$ \\
\hline$\Delta \mathrm{E}^{*}$ & - & $4.84 \pm 0.34^{\mathrm{a}}$ & $2.15 \pm 0.84^{\mathrm{c}}$ & $3.45 \pm 0.33^{\mathrm{b}}$ & $3.94 \pm 0.48^{b}$ \\
\hline
\end{tabular}

a,b,c, Within a line, means \pm standard deviations with different superscript lowercase letters denote significant differences $(P<0.05)$ between the ice creams samples. Ice cream 1 : ice cream produced with pasteurized whole milk. Ice cream 2: ice cream produced with freeze concentrated whey. Ice cream $3:$ ice cream produced with $25 \%$ of freeze concentrated whey and $75 \%$ of pasteurized whole milk. Ice cream 4 : ice cream produced with $50 \%$ of freeze concentrated whey and $50 \%$ of pasteurized whole milk. Ice cream 5 : ice cream produced with $75 \%$ of freeze concentrated whey and $25 \%$ of pasteurized whole milk. 
Figure 4 shows the structure of the ice creams observed by the direct microscopy method. It was verified that the addition of concentrate whey however did not influence the ice cream structures. Fat globule size ranged from $1.60 \pm 0.42$ (ice cream 1) to $2.29 \pm 0.46 \mu \mathrm{m}$ (ice cream 2) showing no significant difference $(P<0.05)$ between ice creams. According to Balthazar et al. (2017b), fat influences the saturation, due to the aggregation induced by the presence of air bubbles when the size of fat globules is larger than $2 \mu \mathrm{m}$. Goff \& Jordan (1989), stated that the addition of whey increases the viscosity of the mixture and influences the destabilization of fat in ice cream. All ice creams samples presented similar average ice crystal sizes $(<50 \mu \mathrm{m} 2)$. According to Balthazar et al. (2017b), most crystals must be bottom than $50 \mu \mathrm{m}$ in size, like ice creams with ice crystals greater than $100 \mu \mathrm{m}$ can cause consumer rejection as it has rough and coarse sensory aspect. Kozlowicz et al. (2019) stated that the amount of total solids is a factor that can have a major impact on the growth and quantity of ice crystals, the scarcity of total solids leads to the increase of ice crystals. Thus, it suggests that

Table 4. Firmness and adhesiveness analysis of the ice creams.

\begin{tabular}{ccc}
\hline Sample & Firmness $(\mathrm{N})$ & Adhesiveness (N.s) \\
\hline Ice cream 1 & $33.36 \pm 1.10^{\mathrm{a}}$ & $-8.03 \pm 0.85^{\mathrm{b}}$ \\
Ice cream 2 & $1.47 \pm 0.10^{\mathrm{c}}$ & $-1.42 \pm 0.40^{\mathrm{a}}$ \\
Ice cream 3 & $7.15 \pm 2.68^{\mathrm{b}}$ & $-2.64 \pm 0.53^{\mathrm{a}}$ \\
Ice cream 4 & $8.16 \pm 1.30^{\mathrm{b}}$ & $-1.81 \pm 0.32^{\mathrm{a}}$ \\
Ice cream 5 & $7.06 \pm 0.27^{\mathrm{b}}$ & $-2.31 \pm 0.60^{\mathrm{a}}$ \\
\hline
\end{tabular}

a,b,c, For the same column, means \pm standard deviations with different superscript lowercase letters denote significant differences $(P<0.05)$ between the ice creams samples. Ice cream 1: ice cream produced with pasteurized whole milk. Ice cream 2: ice cream produced with freeze concentrated whey. Ice cream 3: ice cream produced with $25 \%$ of freeze concentrated whey and $75 \%$ of pasteurized whole milk. Ice cream 4 : ice cream produced with $50 \%$ of freeze concentrated whey and $50 \%$ of pasteurized whole milk. Ice cream 5: ice cream produced with $75 \%$ of freeze concentrated whey and $25 \%$ of pasteurized whole milk. the addition of concentrate whey did not influence $(P<0.05)$ the size of the ice crystals. Mean air bubbles diameter ranged from $2.58 \pm 0.59 \mu \mathrm{m}$ (ice cream 1) to $3.78 \pm 0.68 \mu \mathrm{m}$ (ice cream $2)$, the addition of concentrate whey did not influence the air bubble diameter $(P<0.05)$. Fat may have played a role around air bubbles along with whey proteins present, separating air cells and preventing coalescence, as noted by Chang \& Hartel (2002).

Table 4 presents the firmness and adhesiveness results of the ice cream samples. Regarding the firmness attribute, ice cream 1 appeared firmer, differing from the other ice creams containing concentrate whey $(P<0.05)$. It is important to highlight that the ice cream elaborates only with concentrate whey (ice cream 2 ) was the one that presented the lowest firmness $(P<0.05)$. The addition of concentrate whey affected the firmness of the ice cream, which decreased with the addition of concentrate whey. This behavior is related to the increase in total solids content. The higher the total solids content, the less water to be frozen causing a smoother and creamy texture, a firmer ice cream, and a higher nutritional value. These differences in firmness may also be related to whey proteins, because, according to Ruger et al. (2002), the water retention properties of whey proteins may prevent the increasing ice phase volume of the ice cream and improving the texture.

The addition of concentrate whey also contributed to ice creams with higher values $(P<0.05)$ of adhesiveness. It is believed that the total solids content had a positive influence on the adhesiveness increase. This behavior is in agreement with Kozlowicz et al. (2019), who also observed a correlation between the adhesiveness and the total solids content in ice cream. Karaca et al. (2009) also suggested this behavior occurs because the whey proteins may have simulated the role of fat regarding the texture of the ice creams, this is attributed to their ability to interact with water, proteins, and flavor compounds. The increase in the viscosities of ice creams also contributes to greater adhesiveness.
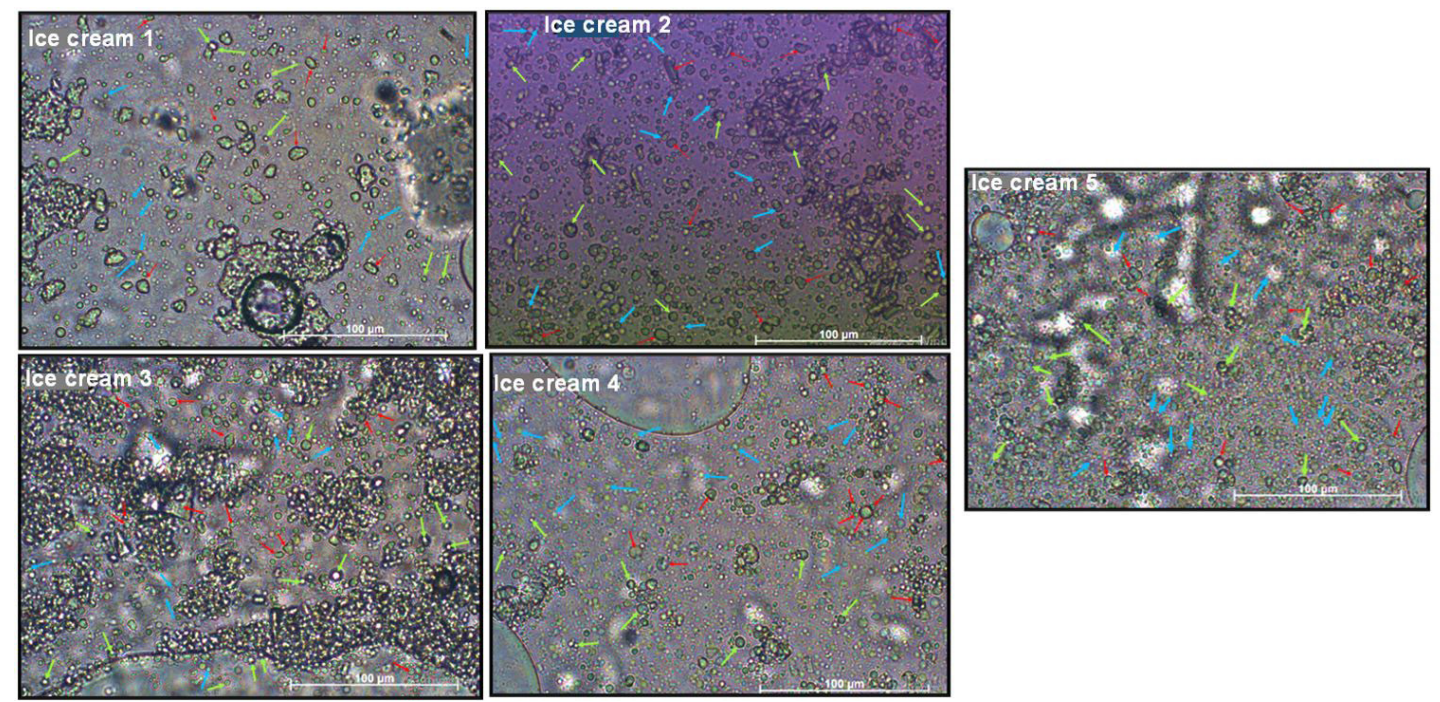

Figure 4. Structure of ice creams containing: pasteurized whole milk (Ice cream 1) freeze concentrated whey (Ice cream 2), 25\% of freeze concentrated whey and $75 \%$ of pasteurized whole milk (Ice cream 3), 50\% of freeze concentrated whey, and $50 \%$ of pasteurized whole milk (Ice cream 4 ) and $75 \%$ of freeze concentrated whey and $25 \%$ of pasteurized whole milk (Ice cream 5 ) observed by direct microscopy method ( $50 \times$ ). Air bubble (Green arrow) $(\rightarrow)$, ice crystal (Red arrow) $(\rightarrow)$, and fat globules (Blue arrow) $(\rightarrow$ ). 
Table 5. Rheological parameters of the ice creams using the Power Law, Casson model, and thixotropic index.

\begin{tabular}{|c|c|c|c|c|c|c|c|}
\hline \multirow{2}{*}{ Sample } & \multicolumn{3}{|c|}{ Power Law Model } & \multicolumn{3}{|c|}{ Casson Model } & \multirow{2}{*}{ Hysteresis } \\
\hline & $\mathrm{K}\left(\mathrm{Pa} \cdot \mathrm{s}^{\mathrm{n}}\right)$ & $n$ & $R^{2}$ & $\sigma_{0}(\mathrm{~Pa})$ & $\eta_{c}(\mathrm{~Pa} \mathrm{~s})$ & $R^{2}$ & \\
\hline Ice cream 1 & $0.013 \pm 0.003^{c}$ & $0.991 \pm 0.039^{\mathrm{a}}$ & 0.994 & $0.003 \pm 0.001^{c}$ & $0.012 \pm 0.001^{c}$ & 0.998 & $2.875 \pm 0.898^{\circ}$ \\
\hline Ice cream 2 & $0.035 \pm 0.008^{\mathrm{a}}$ & $0.907 \pm 0.029^{\mathrm{a}}$ & 0.996 & $0.035 \pm 0.003^{\mathrm{a}}$ & $0.018 \pm 0.001^{\mathrm{a}}$ & 0.998 & $28.268 \pm 6.552^{a}$ \\
\hline Ice cream 3 & $0.019 \pm 0.002^{\mathrm{b}}$ & $0.957 \pm 0.048^{\mathrm{a}}$ & 0.994 & $0.004 \pm 0.001^{c}$ & $0.013 \pm 0.001^{c}$ & 0.999 & $1.034 \pm 0.325^{\circ}$ \\
\hline Ice cream 4 & $0.024 \pm 0.004^{\mathrm{ab}}$ & $0.923 \pm 0.034^{\mathrm{a}}$ & 0.996 & $0.009 \pm 0.001^{\mathrm{b}}$ & $0.014 \pm 0.001^{\mathrm{bc}}$ & 0.998 & $14.321 \pm 0.460^{\circ}$ \\
\hline Ice cream 5 & $0.021 \pm 0.005^{\mathrm{bc}}$ & $0.961 \pm 0.005^{\mathrm{a}}$ & 0.995 & $0.010 \pm 0.001^{\mathrm{b}}$ & $0.016 \pm 0.001^{\mathrm{ab}}$ & 0.996 & $11.071 \pm 2.322^{b}$ \\
\hline
\end{tabular}

Results expressed as means \pm standard deviation, among three lots performed in triplicate for each ice cream sample, with three replications for each rheological parameter; ab,b,d,e $F$ or the same column, different superscript lowercase letters denote significant differences $(P<0.05)$ between the ice creams samples. Ice cream 1: ice cream produced with pasteurized whole milk. Ice cream 2: ice cream produced with freeze concentrated whey. Ice cream 3: ice cream produced with $25 \%$ of freeze concentrated whey and $75 \%$ of pasteurized whole milk. Ice cream 4: ice cream produced with $50 \%$ of freeze concentrated whey and $50 \%$ of pasteurized whole milk. Ice cream 5 : ice cream produced with $75 \%$ of freeze concentrated whey and $25 \%$ of pasteurized whole milk; $\mathrm{K}=$ consistency index; $\mathrm{n}=$ flow behavior index; $\mathrm{R}^{2}=$ correlation coefficients; $\sigma_{0}=$ yield limit; $\eta_{\mathrm{c}}=$ Casson viscosity.

The results of the rheological parameters of the ice creams $(1,2,3,4$, and 5$)$ are presented in Table 5 . It can be observed that the addition of concentrate whey $(P<0.05)$ significantly affected the rheological behavior of the ice creams, improving the viscosity (Figure 5). It was observed that the viscosity of the ice creams remained constant with increasing strain rate, indicating a Newtonian fluid behavior (Figure 5). The ice creams added with concentrate whey showed higher viscosity than the control ice cream, being higher the viscosity with the addition of whey. This behavior occurs due to the higher total solids content of concentrate whey. Rossa et al. (2012) noted that whey protein thermally unfolds in the ice cream mixture and leads to the formation of protein polymers, which can behave like hard spheres, showing high flow resistance, thereby increasing the viscosity of the ice cream.

As verified by Ghandehari Yazdi et al. (2020) the ice creams elaborated in the present work were fitted by the Power law model. Therefore, the Power-law model described well the flow behavior of ice cream with the high correlation coefficient (Table 5), being $(\mathrm{n}=1)$, confirming the Newtonian behavior (Figure 6). The consistency index value was indicative of the flow properties of the ice cream. It was observed that concentrate whey increased the consistency index from $\left(0.013\right.$ Pa. $\left.\mathrm{s}^{\mathrm{n}}\right)$ ice cream 1 to $\left(0.035\right.$ Pa. $\left.\mathrm{s}^{\mathrm{n}}\right)$ ice cream 2 , and consequently, increased the viscosity of ice creams. This behavior can be attributed to the increase in protein content which tends to increase consistency index and viscosity. According to Damodaran (1997), this may be attributed to the large dispersion of denatured protein colloidal particles and casein micelles in the structure of ice cream so different protein sources would impact the consistency, as protein content increased.

The Casson model was adjusted to calculate the Casson yield limit $\left(\sigma_{0}\right)$ and Casson viscosity $\left(\eta_{\mathrm{c}}\right)$ (Table 5$)$. In general, all ice cream samples showed an increase in the Casson yield limit. This behavior could occur due to the increased viscosity of ice creams, caused by the water retention properties of whey proteins. Casson viscosity values were higher in ice creams added with concentrate whey, increasing with the addition of concentrate whey. This increase is associated with the higher total solids content of concentrate whey ice creams samples.

The hysteresis of ice creams $(1,2,3,4$, and 5$)$ are shown in Figure 6. Ice cream 2 was the sample that had the highest consistency index and highest viscosity and the largest hysteresis

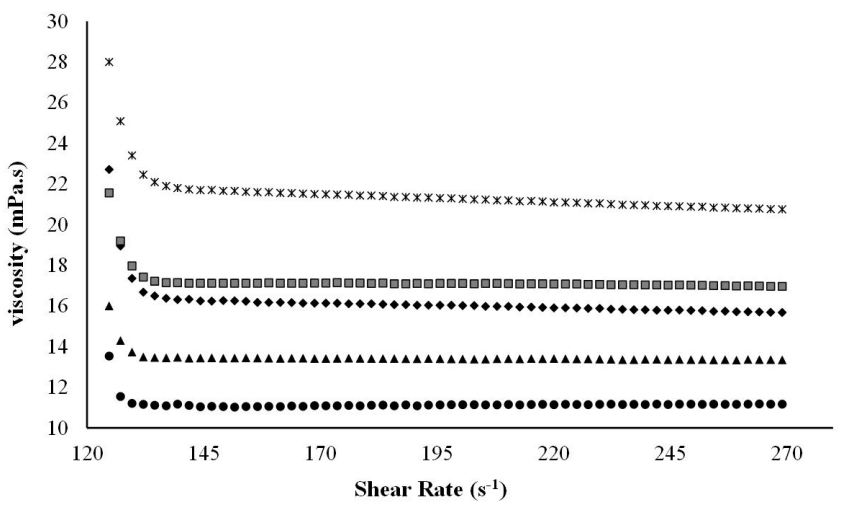

Figure 5. Effect of shear rate on viscosity of ice creams samples. Ice cream $1(\bullet)$ ice cream produced with pasteurized whole milk, freeze concentrated whey - Ice cream $2\left(^{*}\right), 25 \%$ of freeze concentrated whey and $75 \%$ of pasteurized whole milk - Ice cream $3(\boldsymbol{\Delta}), 50 \%$ of freeze concentrated whey and $50 \%$ of pasteurized whole milk - Ice cream 4 $(\downarrow)$ and $75 \%$ of freeze concentrated whey and $25 \%$ of pasteurized whole milk - Ice cream 5 ( $\square)$.

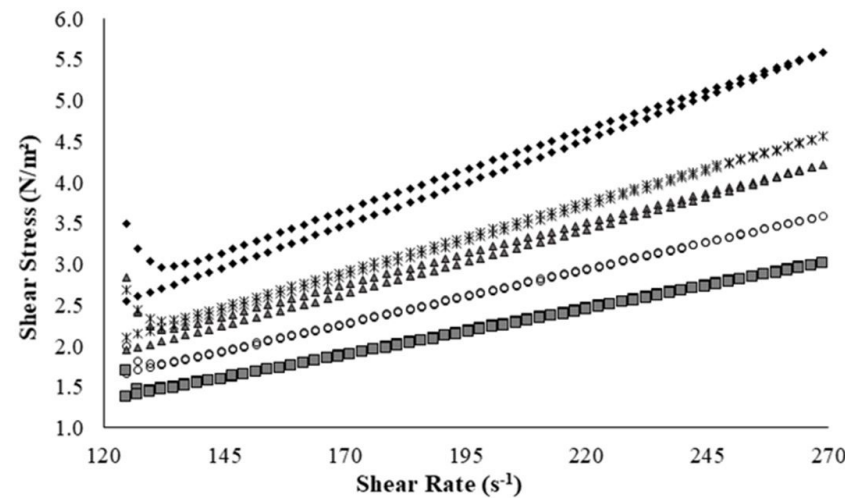

Figure 6. Flow curves, shear stress versus shear rate, for ice cream produced with pasteurized whole milk - Ice cream 1 ( $\square$ ), freeze concentrated whey - Ice cream $2(\diamond) 25 \%$ of freeze concentrated whey and $75 \%$ of pasteurized whole milk - Ice cream 3 (०), 50\% of freeze concentrated whey and $50 \%$ of pasteurized whole milk - Ice cream $4(\boldsymbol{\Delta})$ and $75 \%$ of freeze concentrated whey and $25 \%$ of pasteurized whole milk - Ice cream $\left.5{ }^{*}\right)$.

area $(P<0.05)$ (Table 5). Rossa et al. $(2012)$ state that a higher viscosity thixotropic fluid may show a larger hysteresis area than a lower viscosity fluid, even if this one suffers a breakdown of the 
less viscous product structure. The largest hysteresis area of ice cream added with concentrate whey is also related to the high amount of total solids, as shown in Table 3. Mohameed et al. (2004) related the concentration of solids with changes in rheological properties.

Finally, the results obtained in this study showed that the use of freeze concentrate whey in the preparation of ice creams is an attractive alternative for the food industry, once the ice cream is a product of expressive market that pleases several consumers and have significant nutritional qualities.

\section{Conclusion}

The use of block freeze concentrated technology applied in the whey has contributed to an economical, natural ingredient and with a high nutritional value that can be added in the ice cream preparation. The concentrated whey of the second stage was chosen for the preparation of the ice cream. All ice creams samples showed an increase in total solids and titratable acidity, and a decrease in $\mathrm{pH}$ values. Overrun ranged from 27 to $44 \%$. Ice creams with of concentrate whey retained their original shape longer. All the ice creams had crystal ice sizes, fat globules, and the diameter of air bubbles similar. The ice creams with milk showed higher whiteness, while the ice creams with concentrate whey addition presented a higher tendency to yellow and greenish color. The Power Law and Casson models described well the flow of all ice creams, which presented the behavior of Newtonian fluids. The addition of concentrated whey contributed to an increase in viscosity, consistency index, and hysteresis area of ice creams. Therefore, it was observed that replacing $50 \%$ of whole milk with concentrate whey provides a better formulation, choosing ice cream 4 due to its higher overrun.

\section{Acknowledgements}

The authors are grateful to $\mathrm{CNPq}$ (National Council for Scientific and Technological Development, Brazil) for the financial support [CNPq, 405965/2016-8], and to CAPES (Coordination of Improvement of Higher Education Personnel, Brazil - Finance Code 001) by the scholarship.

\section{References}

Acu, M., Kinic, O., \& Yerlikaya, O. (2020). Probiotic viability, viscosity, hardness properties and sensorial quality of synbiotic ice creams produced from goat's milk. Food Science and Technology (Campinas), 41(1), 167-173. http://dx.doi.org/10.1590/fst.39419.

Al, M., Ersöz, F., Özaktaş, T., Türkanoğlu-Özçelik, A., \& Küçükçetin, A. (2020). Comparison of the effects of adding microbial transglutaminase to milk and ice cream mixture on the properties of ice cream. International Journal of Dairy Technology, 73(3), 578-584. http:// dx.doi.org/10.1111/1471-0307.12707.

Association of Official Analytical Chemists - AOAC. (2019). Official methods of analysis of the Association of Official Analytical Chemists. Washington: AOAC

BahramParvar, M., Tehrani, M. M., Razavi, S. M. A., \& Koocheki, A. (2015). Application of simplex-centroid mixture design to optimize stabilizer combinations for ice cream manufacture. Journal of Food
Science and Technology, 52(3), 1480-1488. http://dx.doi.org/10.1007/ s13197-013-1133-5. PMid:25745216.

Balthazar, C. F., Silva, H. L. A., Cavalcanti, R. N., Esmerino, E. A., Cappato, L. P., Abud, Y. K. D., Moraes, J., Andrade, M. M., Freitas, M. Q., Sant'Anna, C., Raices, R. S. L., Silva, M. C., \& Cruz, A. G. (2017a). Prebiotics addition in sheep milk ice cream: a rheological, microstructural and sensory study. Journal of Functional Foods, 35, 564-573. http://dx.doi.org/10.1016/j.jff.2017.06.004.

Balthazar, C. F., Silva, H. L. A., Vieira, A. H., Neto, R. P. C., Cappato, L. P., Coimbra, P. T., Moraes, J., Andrade, M. M., Calado, V. M. A., Granato, D., Freitas, M. Q., Tavares, M. I. B., Raices, R. S. L., Silva, M. C., \& Cruz, A. G. (2017b). Assessing the effects of different prebiotic dietary oligosaccharides in sheep milk ice cream. Food Research International, 91, 38-46. http://dx.doi.org/10.1016/j. foodres.2016.11.008. PMid:28290325.

Balthazar, C. F., Silva, H. L. A., Esmerino, E. A., Rocha, R. S., Moraes, J., Carmo, M. A. V., Azevedo, L., Camps, I., K.D Abud, Y., Sant'Anna, C., Franco, R. M., Freitas, M. Q., Silva, M. C., Raices, R. S. L., Escher, G. B., Granato, D., Senaka Ranadheera, C., Nazarro, F., \& Cruz, A. G. (2018). The addition of inulin and Lactobacillus casei 01 in sheep milk ice cream. Food Chemistry, 246, 464-472. http://dx.doi. org/10.1016/j.foodchem.2017.12.002. PMid:29291874.

Canella, M. H. M., Munoz, I. B., Pinto, S. S., de Liz, G. R., Muller, C. M. O., Amboni, R. D. M. C., \& Prudencio, E. S. (2018). Use of concentrated whey by freeze concentration process to obtain a symbiotic fermented lactic beverage. Advance Journal of Food Science and Technology, 14(2), 56-68. http://dx.doi.org/10.19026/ ajfst.14.5832.

Canella, M. H. M., Muñoz, I. B., Barros, E. L. S., Silva, C. C., Ploêncio, L. A. S., Daguer, H., \& Prudêncio, E. S. (2019). Block freeze concentration as a technique aiming the goatmilk concentration: fate of physical, chemical, and rheological properties. International Journal of Engineering Sciences \& Research Technology, 8(5), 87-104. http://dx.doi.org/10.5281/zenodo.2836603.

Chang, Y., \& Hartel, R. W. (2002). Development of air cells in a batch ice cream freezer. Journal of Food Engineering, 55(1), 71-78. http:// dx.doi.org/10.1016/S0260-8774(01)00243-6.

Damodaran, S. (1997). Protein-stabilized foams and emulsions. In: Damodaran S, Paraf A, editors. Food proteins and their applications (pp. 57-110). New York: Marcel Dekker.

Ghandehari Yazdi, A. P., Barzegar, M., Ahmadi Gavlighi, H., Sahari, M. A., \& Mohammadian, A. H. (2020). Physicochemical properties and organoleptic aspects of ice cream enriched with microencapsulated pistachio peel extract. International Journal of Dairy Technology, 73(3), 570-577. http://dx.doi.org/10.1111/1471-0307.12698.

Goff, H., \& Jordan, W. (1989). Action of emulsifiers in promoting fat destabilization during the manufacture of ice cream. Journal of Dairy Science, 72(1), 18-29. http://dx.doi.org/10.3168/jds.S00220302(89)79075-5.

Hasan, G. M., Saadi, A. M., \& Jassim, M. A. (2020). Study the effect of replacing the skim milk used in making ice cream with some dried fruit. Food Science and Technology (Campinas). In press. http:// dx.doi.org/10.1590/fst.29620.

International Dairy Federation - IDF. (2013). Ice cream and milk icedetermination of total solids content. Brussels: International Dairy Federation.

Karaca, O. B., Güven, M., Yasar, K., Kaya, S., \& Kahyaoglu, T. (2009). The functional, rheological and sensory characteristics of ice creams with various fat replacers. International Journal of Dairy Technology, 62(1), 93-99. http://dx.doi.org/10.1111/j.1471-0307.2008.00456.x. 
Kirtil, E., \& Oztop, M. H. (2016). Characterization of emulsion stabilization properties of quince seed extract as a new source of hydrocolloid. Food Research International, 85, 84-94. http://dx.doi. org/10.1016/j.foodres.2016.04.019. PMid:29544856.

Kozlowicz, K., Góral, M., Góral, D., Pankiewicz, U., \& BronowickaMielniczuk, U. (2019). Effect of ice cream storage on the physicochemical properties and survival of probiotic bacteria supplemented with zinc ions. Lebensmittel-Wissenschaft + Technologie, 116, 108562. http:// dx.doi.org/10.1016/j.lwt.2019.108562.

Levin, M. A., Burrington, K. J., \& Hartel, R. W. (2016). Whey protein phospholipid concentrate and delactosed permeate: Applications in caramel, ice cream, and cake. Journal of Dairy Science, 99(9), 69486960. http://dx.doi.org/10.3168/jds.2016-10975. PMid:27344387.

Martínez-Cervera, S., Salvador, A., Muguerza, B., Moulay, L., \& Fiszman, S. M. (2011). Cocoa fibre and its application as a fat replacer in chocolate muffins. Lebensmittel-Wissenschaft + Technologie, 44(3), 729-736. http://dx.doi.org/10.1016/j.lwt.2010.06.035.

Masotti, F., Cattaneo, S., Stuknyte, M., \& De Noni, I. (2017). Technological tools to include whey proteins in cheese: current status and perspectives. Trends in Food Science \& Technology, 64, 102-114. http://dx.doi.org/10.1016/j.tifs.2017.04.007.

Mohameed, H. A., Abu-JdayiL, B., \& Al-Shawabkeh, A. (2004). Effect of solids concentration on the rheology of labneh (concentrated yogurt) produced from sheep milk. Journal of Food Engineering, 61(3), 347-352. http://dx.doi.org/10.1016/S0260-8774(03)00139-0.

Okpala, C. O. R., Piggott, J. R., \& Schaschke, C. J. (2010). Influence of high-pressure processing (HPP) on physico-chemical properties of fresh cheese. Innovative Food Science \& Emerging Technologies, 11(1), 61-67. http://dx.doi.org/10.1016/j.ifset.2009.10.003.

Relkin, P., \& Sourdet, S. (2005). Factors affecting fat droplet aggregation in whipped frozen protein-stabilized emulsions. Food Hydrocolloids, 19(3), 503-511. http://dx.doi.org/10.1016/j.foodhyd.2004.10.015.

Rodrigues, D., Sousa, S., Rocha-Santos, T., Silva, J. P., Sousa Lobo, J. M., Costa, P., Amaral, M. H., Pintado, M. M., Gomes, A. M., Malcata, F.
X., \& Freitas, A. C. (2011). Influence of l-cysteine, oxygen and relative humidity upon survival throughout storage of probiotic bacteria in whey protein-based microcapsules. International Dairy Journal, 21(11), 869-876. http://dx.doi.org/10.1016/j.idairyj.2011.05.005.

Rossa, P. N., Burin, V. M., \& Bordignon-Luiz, M. T. (2012). Effect of microbial transglutaminase on functional and rheological properties of ice cream with different fat contents. Lebensmittel-Wissenschaft + Technologie, 48(2), 224-230. http://dx.doi.org/10.1016/j.lwt.2012.03.017.

Ruger, P. R., Baer, R. J., \& Kasperson, K. M. (2002). Effect of Double Homogenization and Whey Protein Concentrate on the Texture of Ice Cream. Journal of Dairy Science, 85(7), 1684-1692. http:// dx.doi.org/10.3168/jds.S0022-0302(02)74241-0. PMid:12201518.

Sánchez, J., Hernández, E., Auleda, J. M., \& Raventós, M. (2011a). Review: Freeze Concentration Technology Applied to Dairy Products. Food Science \& Technology International, 17(1), 5-13. http://dx.doi. org/10.1177/1082013210382479. PMid:21364040.

Sánchez, J., Hernández, E., Auleda, J. M., \& Raventós, M. (2011b). Freeze concentration of whey in a falling-film based pilot plant: Process and characterization. Journal of Food Engineering, 103(2), 147-155. http://dx.doi.org/10.1016/j.jfoodeng.2010.10.009.

Scarso, S., McParland, S., Visentin, G., Berry, D. P., McDermott, A., \& De Marchi, M. (2017). Genetic and nongenetic factors associated with milk color in dairy cows. Journal of Dairy Science, 100(9), 73457361. http://dx.doi.org/10.3168/jds.2016-11683. PMid:28711262.

Silva, K., \& Bolini, H. M. A. (2006). Avaliação sensorial de sorvete formulado com produto de soro ácido de leite bovino. Food Science and Technology (Campinas), 26(1), 116-122. http://dx.doi.org/10.1590/ S0101-20612006000100020.

Silva, P. D. L., Bezerra, M. F., Santos, K. M. O., \& Correia, R. T. P. (2015). Potentially probiotic ice cream from goat's milk: Characterization and cell viability during processing, storage and simulated gastrointestinal conditions. Lebensmittel-Wissenschaft + Technologie, 62(1), 452-457. http://dx.doi.org/10.1016/j.lwt.2014.02.055. 